\title{
Physiological and taxonomic description of the novel autotrophic, metal oxidizing bacterium, Pseudogulbenkiania sp. strain 2002
}

\author{
Karrie A. Weber • David B. Hedrick • \\ Aaron D. Peacock • J. Cameron Thrash • \\ David C. White • Laurie A. Achenbach • John D. Coates
}

Received: 11 December 2008 /Revised: 9 February 2009 /Accepted: 25 February 2009 / Published online: 31 March 2009

(C) The Author(s) 2009. This article is published with open access at Springerlink.com

\begin{abstract}
A lithoautotrophic, Fe(II) oxidizing, nitratereducing bacterium, strain 2002 (ATCC BAA-1479; =DSM 18807), was isolated as part of a study on nitrate-dependent Fe (II) oxidation in freshwater lake sediments. Here we provide an in-depth phenotypic and phylogenetic description of the isolate. Strain 2002 is a gram-negative, non-spore forming, motile, rod-shaped bacterium which tested positive for oxidase, catalase, and urease. Analysis of the complete $16 \mathrm{~S}$ rRNA gene sequence placed strain 2002 in a clade within the family Neisseriaceae in the order Nessieriales of the Betaproteobacteria $99.3 \%$ similar to Pseudogulbenkiania
\end{abstract}

The GenBank accession number for the 16S rRNA gene sequence of strain 2002 is AY609199

Strain 2002 was deposited in the American Type Culture Collection as well as the Deutsche Sammlung von Mikroorganismen und

Zellkulturen $\mathrm{GmbH}$ under the following accession numbers: ATCC

BAA-1479; =DSM 18807.

K. A. Weber J. C. Thrash · J. D. Coates $(\bowtie)$

Department of Plant and Microbial Biology,

University of California,

Berkeley, CA 94720, USA

e-mail: jcoates@nature.berkeley.edu

D. B. Hedrick - A. D. Peacock - D. C. White

Center for Biomarker Analysis, University of Tennessee,

Knoxville, TN 37932, USA

L. A. Achenbach

Department of Microbiology, Southern Illinois University,

Carbondale, IL 62901, USA

Present Address:

K. A. Weber

Department of Geosciences, University of Nebraska,

Lincoln, NE 68588-0340, USA subflava. Similar to $P$. sublfava, predominant whole cell fatty acids were identified as $16: 17 \mathrm{c}, 42.4 \%$, and $16: 0$, $34.1 \%$. Whole cell difference spectra of the $\mathrm{Fe}$ (II) reduced minus nitrate oxidized cyctochrome content revealed a possible role of $c$-type cytochromes in nitrate-dependent $\mathrm{Fe}$ (II) oxidation. Strain 2002 was unable to oxidize aqueous or solid-phase $\mathrm{Mn}$ (II) with nitrate as the electron acceptor. In addition to lithotrophic growth with Fe(II), strain 2002 could alternatively grow heterotrophically with long-chain fatty acids, simple organic acids, carbohydrates, yeast extract, or casamino acids. Nitrate, nitrite, nitrous oxide, and oxygen also served as terminal electron acceptors with acetate as the electron donor.

Keyword Fe(II) oxidation · Anaerobic · Nitrate ·

Bioremediation · Uranium

\section{Introduction}

Microbial oxidation of $\mathrm{Fe}^{2+}$ and solid-phase $\mathrm{Fe}(\mathrm{II})$-bearing minerals can significantly affect the geochemistry of saturated soils and sediments by the formation of reactive $\mathrm{Fe}(\mathrm{III})$ minerals, including mixed $\mathrm{Fe}$ (II)-Fe(III) minerals, which may result in the sorption or coprecipitation of metals and/or nutrients (Chaudhuri et al. 2001; Cornell \& Schwertmann 2003; Lack et al. 2002b; Weber et al. 2001; Weber et al. 2006c). In recent years, the demonstration of anaerobic microbial $\mathrm{Fe}(\mathrm{II})$ oxidation, light-dependent or nitrate-dependent, has been identified as a mechanism in which biological re-oxidation of $\mathrm{Fe}(\mathrm{II})$ in an anoxic environment can occur (Straub et al. 1996; Weber et al. 2006a; Widdel et al. 1993). To date, several microorganisms have been identified that are capable of anaerobic $\mathrm{Fe}$ 
(II) oxidation (Bruce et al. 1999; Chaudhuri et al. 2001; Edwards et al. 2003; Finneran et al. 2002; Hafenbradl et al. 1996; Lack et al. 2002a; Straub et al. 1996; Straub et al. 1999; Widdel et al. 1993), however, few of these grow by the metabolism (Weber et al. 2006a). Given that light penetration of soil and particulate matter is only between 8 to $200 \mu \mathrm{m}$ (Ciania et al. 2005), light independent reactions such as nitrate-dependent $\mathrm{Fe}(\mathrm{II})$ oxidation are more likely to dominate bio-oxidative processes in saturated and subsurface soil/sedimentary environments.

Nitrate-dependent Fe(II)-oxidizing microorganisms have been identified in both the Archaea and Bacteria (Weber et al. 2006a). Among the isolates currently described only a hyperthermophilic archaeum (Hafenbradl et al. 1996) and the Betaproteobacterium strain 2002 (Weber et al. 2006b) have been demonstrated to oxidize $\mathrm{Fe}(\mathrm{II})$ as the sole electron donor and couple this metabolism to autotrophic growth. For all other isolates described to date either growth was not demonstrated or a co-substrate (acetate or $\mathrm{H}_{2}$ ) was required under iron oxidizing conditions (Benz et al. 1998; Chaudhuri et al. 2001; Edwards et al. 2003; Finneran et al. 2002; Lack et al. 2002a; Sheloblina et al. 2003; Straub \& Buchholz-Cleven 1998; Straub et al. 1996; Straub et al. 2004). To date, the only other microbial isolate in pure culture capable of autotrophic growth with $\mathrm{Fe}(\mathrm{II})$ as the sole electron donor and nitrate as a terminal electron acceptor is the hyperthermophilic archaeum, Ferroglobus placidus (Hafenbradl et al. 1996). It is worthwhile to note that under autotrophic growth conditions Thiobacillus denitrificans has also been demonstrated to oxidize metals coupled to nitrate reduction; however, metal oxidation is dependent on $\mathrm{H}_{2}$ as a co-electron donor (Beller 2005; Beller et al. 2009). It is unclear if Fe(II) could serve as the sole electron donor for nitrate reduction in this bacterium.

Strain 2002 was isolated from a nitrate-dependent Fe(II) oxidizing microbial community in freshwater lake sediments (Weber et al. 2006b). The natural abundance of strain 2002 within the freshwater lake sediment was estimated at $2.4 \times 10^{3}$ cells $\mathrm{g}^{-1}$ wet sediment based on most probable number enumeration studies (Weber et al. 2006b). Strain 2002 was described as a member of the family Nesseriaceae (Weber et al. 2006b). This family is comprised of organisms commonly identified as environmental bacteria as well as mammalian, avian, and invertebrate pathogens and commensals (Corpe 1951; Gillis \& Logan 2005; Hungria et al. 2005; Thomsen et al. 2007; Weber et al. 2006c). From among the environmentally relevant genera of the Nesseriaceae, Chromobacterium spp. are frequently identified in freshwater aquatic environments, soils, and sediments (Corpe 1951; Gillis \& Logan 2005; Hungria et al. 2005; Thomsen et al. 2007; Weber et al. 2006c). The metabolic versatility of Chromobacterium spp., specifically C. violaceum, has resulted in a variety of industrial applications (Vasconcelos et al. 2003). Related to metal biogeochemistry, the biogenic production of cyanide during aerobic growth of $C$. violaceum has been demonstrated to mobilize precious metals such as silver, gold, and platinum as a result of the formation of metal-cyanide aqueous complexes (Brandl et al. 2007; Reith et al. 2007). The ability of this microorganism to oxidize aqueous $\mathrm{Fe}$ (II) to an insoluble $\mathrm{Fe}$ (III) oxide mineral under anaerobic conditions at neutral $\mathrm{pH}$ in addition to strain 2002 was recently demonstrated (Weber et al. 2006b). However, similar to many other known $\mathrm{Fe}(\mathrm{II})$-oxidizing organisms, C. violaceum did not grow by this metabolism (Weber et al. 2006b). The coprecipitation of heavy metal and radionuclide contaminants with biogenic Fe(III) oxides has been proposed as a bioremediation strategy (Lack et al. 2002b). Thus, implicating the role of members within the family Nesseriaceae to participate in metal biogeochemical cycling. Because of its associated growth, strain 2002 presents a novel opportunity to study nitrate- dependent metal oxidation and the environmental implications of this microbial metabolism in pure culture. However, it is first necessary to detail the taxonomic and physiological characteristics of this microorganism for further study. Here we further describe the physiology and phylogenetic placement of the novel lithoautotrophic, nitrate-dependent Fe(II) oxidizing bacterium, strain 2002, as a member of the recently described genus Pseudogulbenkiania in relation to closely related genera in the family Nesseriaceae.

\section{Materials and methods}

Source and culturing of microorganisms Strain 2002 (ATCC BAA-1479; =DSM 18807) was previously isolated from a nitrate-dependent $\mathrm{Fe}(\mathrm{II})$ oxidizing most probable number enumeration series initiated from sediments collected from a freshwater lake, Southern Illinois University campus, Carbondale, Illinois (Weber et al. 2006b) and maintained on freshwater basal medium. Freshwater basal medium contained the following components $\left(1^{-1}\right): 0.25 \mathrm{~g}$ $\mathrm{NH}_{4} \mathrm{Cl}, 0.6 \mathrm{~g} \mathrm{NaH}_{2} \mathrm{PO}_{4}, 0.1 \mathrm{~g} \mathrm{KCl}, 0.42 \mathrm{~g} \mathrm{NaNO}_{3}$, and $2.52 \mathrm{~g} \mathrm{NaHCO}_{3}$. The vitamin and trace mineral solution was added from sterile stock solution $\left(10 \mathrm{ml} \mathrm{l}^{-1}\right)$. The vitamin solution contained $\left(\mathrm{l}^{-1}\right)$ : $2 \mathrm{mg}$ D-biotin, $2 \mathrm{mg}$ folic acid, $10 \mathrm{mg}$ pyridoxine $\mathrm{HCl}, 5 \mathrm{mg}$ riboflavin, $5 \mathrm{mg}$ thiamine, $5 \mathrm{mg}$ nicotinic acid, $5 \mathrm{mg}$ pantothenic acid, $0.1 \mathrm{mg}$ vitamin B12, $5 \mathrm{mg}$-amino benzoic acid, and $5 \mathrm{mg}$ D,L-6,8-thiotic cid. The trace mineral solution was prepared by dissolving the following in a $1.5 \mathrm{~g} \mathrm{l}^{-1}$ nitrilotriacetic acid disodium salt solution $\left(\mathrm{l}^{-1}\right): 3 \mathrm{~g} \mathrm{MgSO}_{4} \cdot 7 \mathrm{H}_{2} \mathrm{O}, 0.5 \mathrm{~g}$ $\mathrm{MnSO}_{4}, 1.0 \mathrm{~g} \mathrm{NaCl}, 0.1 \mathrm{~g} \mathrm{FeSO}_{4} \cdot 7 \mathrm{H}_{2} \mathrm{O}, 0.1 \mathrm{~g} \mathrm{CaCl}_{2} \cdot 2 \mathrm{H}_{2} \mathrm{O}$, $0.1 \mathrm{~g} \mathrm{CoCl}_{2} \cdot 6 \mathrm{H}_{2} \mathrm{O}, 0.13 \mathrm{~g} \mathrm{ZnCl}, 0.01 \mathrm{~g} \mathrm{CuSO}_{4} \cdot 5 \mathrm{H}_{2} \mathrm{O}$, $0.01 \mathrm{AlK}\left(\mathrm{SO}_{4}\right)_{2} \cdot 12 \mathrm{H}_{2} \mathrm{O}, 0.01 \mathrm{~g} \mathrm{H}_{3} \mathrm{BO}_{3}, 0.025 \mathrm{~g} \mathrm{Na}$ 
$\mathrm{MoO}_{4} \cdot 2 \mathrm{H}_{2} \mathrm{O}, 0.024 \mathrm{~g} \mathrm{NiCl}_{2} \cdot 6 \mathrm{H}_{2} \mathrm{O}, 0.025 \mathrm{~g} \mathrm{Na}_{2} \mathrm{WO}_{4} \cdot 2 \mathrm{H}_{2} \mathrm{O}$, $0.02 \mathrm{~g} \mathrm{Na}_{2} \mathrm{SeO}_{4}$. Anoxic freshwater basal medium was prepared by heating the solution to $100^{\circ} \mathrm{C}$ and immediately cooling it to room temperature under an anoxic atmosphere $\left(\mathrm{N}_{2}: \mathrm{CO}_{2} ; 80: 20\right)$. The anoxic basal medium was then dispensed into pressure tubes under an $\mathrm{N}_{2}: \mathrm{CO}_{2}$ atmosphere $(80: 20, v / v)$, sealed with blue butyl stoppers, and autoclaved. Fe(II) source was added from a concentrated anoxic sterile stock solution to achieve a final concentration of $10 \mathrm{mM}$. A concentrated soluble sterile Fe(II) stock solution (1 M) was prepared by adding $\mathrm{FeCl}_{2}$ to anoxic $\left(100 \% \mathrm{~N}_{2}\right.$ headspace) distilled deionized water and sealed with a blue butyl stopper under an anoxic atmosphere $\left(100 \% \quad \mathrm{~N}_{2}\right.$ headspace). The solution was filter sterilized by passing the solution directly through a sterile $0.22 \mu \mathrm{m}$ nylon filter and sterile needle into a sterile, anoxic $\left(100 \% \quad \mathrm{~N}_{2}\right.$ headspace), stoppered serum bottle. For the purposes of this study, strain $2002^{\mathrm{T}}$ was routinely maintained under anaerobic conditions on basal medium with a soluble electron donor and acceptor, acetate $(10 \mathrm{mM})$ and nitrate $(10 \mathrm{mM})$ respectively. Standard anaerobic microbiological culture techniques were employed as previously described (Hungate 1969). Studies determining the optimal $\mathrm{pH}$, temperature, and salinity were carried out on basal medium containing sodium acetate $(10 \mathrm{mM})$ and sodium nitrate $(10 \mathrm{mM})$.

Electron donors and acceptors The ability of strain 2002 to utilize alternative electron donors and acceptors was tested by adding chemicals from anoxic, sterile stock solutions to freshwater basal medium as described above. Ferric iron was added from a filter sterilized $1 \mathrm{M}$ soluble iron stock solution prepared as previously described by dissolving nitrilotriacetic acid disodium salt (NTA), sodium bicarbonate, and ferric chloride (Roden \& Lovely 1993). Benzene, toluene, and hexadecane were added directly to culture medium. Growth after three successive transfers was recorded as positive. Growth was determined by changes in optical density at $600 \mathrm{~nm}$. In cultures containing solidphase electron donors and/or acceptors cell density was monitored by direct cell counts (Petroff-Hausser Counter, $0.02 \mathrm{~mm}$ depth). Samples collected for direct cell counts were immediately fixed in formaldehyde (final concentration $3.7 \%$ ).

Analytical techniques Ion chromatrography with conductivity detection (IonPac ${ }^{\circledR}$ AS9-HC analytical column, Dionex DX-500 system, Dionex Corp., Sunnyvale, CA). was used to analyze $\mathrm{NO}_{3}{ }^{-}$and $\mathrm{NO}_{2}{ }^{-}$. Concentrations of $\mathrm{NH}_{4}{ }^{+}$in growth experiments were determined spectrophotometrically according to Wetzel \& Likens (1991). Batch culture headspace $\mathrm{N}_{2}$ was quantified using a gas chromatograph equipped with a thermal conductivity detector (Shimadzu GC-8A; Porapak N, 80-100 mesh, $12 \mathrm{ft} . \times 1 / 8$ in. column).

Electron microscopy Cells for electron microscopy were grown anaerobically in freshwater basal medium (described above) amended with acetate $(10 \mathrm{mM})$ and $\mathrm{NO}_{3}{ }^{-}(10 \mathrm{mM})$. Cells were harvested by centrifugation during log growth phase under an anaerobic atmosphere $\left(\mathrm{N}_{2}: \mathrm{CO}_{2} ; 80: 20\right)$, washed twice with $0.1 \mathrm{M}$ sodium cacodylate buffer $\mathrm{pH} 7.2$, and fixed with glutaraldehyde (final concentration $3 \% v / v$ ). Cells were then resuspended in $1 \%$ osmium tetroxide in sodium cacodylate buffer for $2 \mathrm{~h}$ and rinsed in sodium cacodylate buffer. Cells were dehydrated subsequently for $10 \mathrm{~min}$ in $35 \%, 50 \%, 70 \%, 80 \%, 95 \%, 100 \%$, and $100 \%$ ethanol followed by critical point drying. Cells were mounted onto stubs and sputter coated with palladium/gold and viewed with a Hitachi S5000 scanning electron microscope at $20 \mathrm{kV}$.

Phospholipid fatty acids, DNA base composition, and phylogenetic analyses Major phospholipid fatty acids of strain $2002^{\mathrm{T}}$ were determined using methods described by Singleton et al. (2003) when grown under heterotrophic (10 mM acetate and $10 \mathrm{mM}$ nitrate) and lithoautotrophic (10 $\mathrm{mM} \mathrm{Fe}(\mathrm{II})$ and $5 \mathrm{mM}$ nitrate) conditions. Whole cell fatty acids of strain 2002 and pure culture relatives, Chromobacterium violaceum ATCC $12472^{\mathrm{T}}$, Chromobacterium subtsugae PRAA4-1 ${ }^{\mathrm{T}}$, Aquitalea magnusonii TRO-001-1DR8 ${ }^{\mathrm{T}}$, and Gulbenkiania mobilis $\mathrm{E} 4 \mathrm{FC} 31^{\mathrm{T}}$, grown aerobically on tryptic soy agar were determined as previously described (Komagata \& Suzuki 1987; MIDI 2001). G + C content of strain 2002 was calculated from the ratio of deoxyguanosine $(\mathrm{dG})$ and thymidine (dT) as previously described (Mesbah et al. 1989).

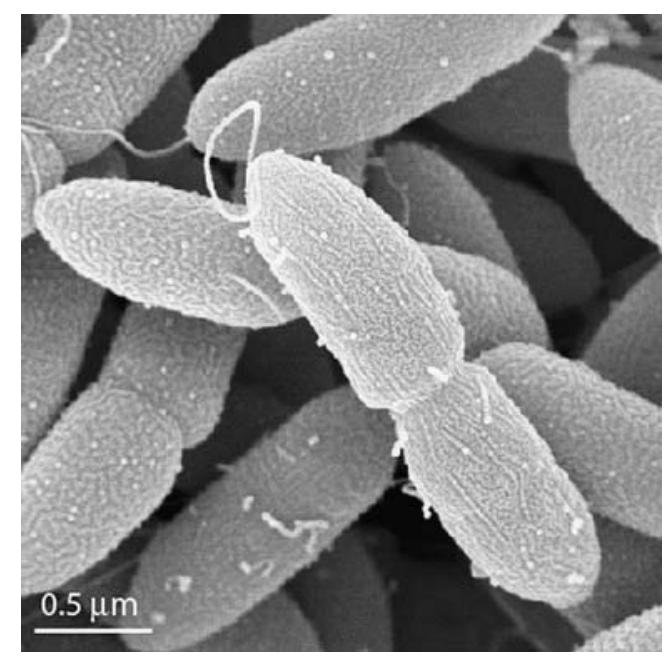

Fig. 1 Scanning electron micrograph of strain 2002 grown under heterotrophic nitrate reducing conditions, $10 \mathrm{mM}$ acetate and $10 \mathrm{mM}$ nitrate. Bar denotes image scale, $0.5 \mu \mathrm{m}$ 
Phylogenetic analysis was conducted using 1395 MUSCLE aligned characters from the 16S rRNA gene sequences of members from strain 2002 (AY609199), close relatives, and the family Neisseriaceae as follows: Pseudogulbenkiania subflava (EF626692), clone JH WH6 (EF492895), Paludimonas yongneupensis (AM396358), Gulbenkiania mobilis (AM295491), Chromobacterium violaceum (M22510), Chromobacterium str. MBIC3901 (AB017487), Chromobacterium
Fig. 2 Bayesian consensus phylogenetic tree of 1,359 aligned characters from the 16S rRNA gene sequence of strain 2002 and members of the family Neisseriaceae after 4,000,000 generations with a sample frequency of 1,000 . Results from Bayesian posterior probability are indicated at the nodes as follows: filled circle 1.00, empty circle $>0.90$, filled square, 0.80 0.90 ; empty square $<0.80$. Methylophilus methylotrophus, a member of the family Methylophilaceae within the Betaproteobacteria, served as the outgroup. The same topology was obtained with maximumlikelihood analysis

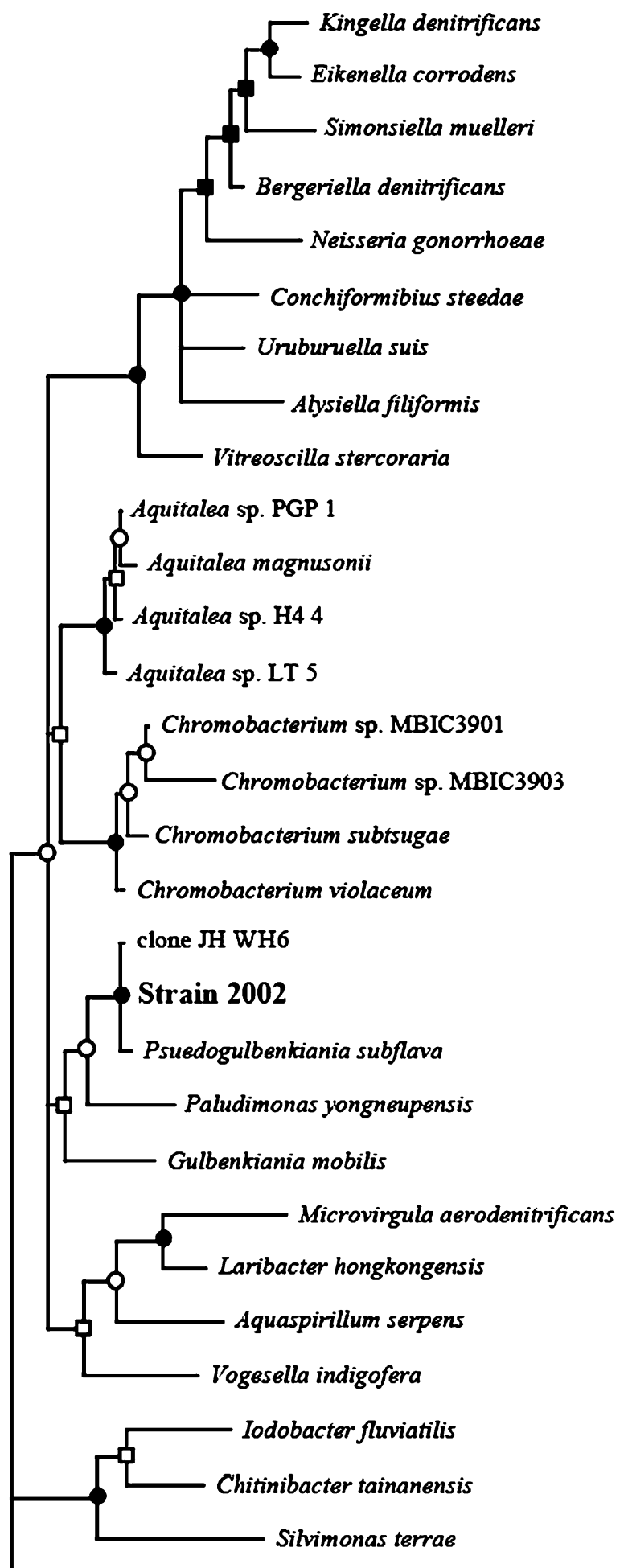

Silvimonas terrae 
str. MBIC3903 (AB017489), Chromobacterium subtsugae (AY344056), Aquitalea magnusonii (DQ018117), Aquitalea sp. LT 5 (EU287928), Aquitalea sp. H4 4 (AB277845), Aquitalea sp. PGP 1 (AB277847), (L06174), Alysiella filiformis (AB087263), Uruburuella suis (AJ586614), Conchiformibius steedae (AF328153), Neisseria gonorrhoeae (X07714), Bergeriella denitrificans (L06173), Simonsiella muelleri (AF328147), Eikenella corrodens (M22512), Kingella denitrificans (M22516), Vogesella indigofera (AB021385), Aquaspirillum serpens (AB074518), Microvirgula aerodenitrificans, (U89333), Laribacter hongkongensis (AF389085), Iodobacter fluviatilis (M22511), Chitinibacter tainanensis (AY264287), and Silvimonas terrae (AB194302) with Methylophilus methylotrophus (M29021) as the outgroup. Bayesian consensus analysis of aligned 16S rRNA gene sequences was performed using MRBAYES using GTR + gamma model of evolution for 4,000,000 generations with a tree sample frequency every 1,000 generations creating a posterior probability distribution (Huelsenbeck \& Ronquist 2001). The alignments were also subjected to maximumlikelihood analysis in Bio-Edit version 7.0.9.0 using default parameters (Hall 1999).

\section{Results}

Cell morphology and growth conditions Cells of strain 2002 as previously described (Weber et al. 2006b) were rod-shaped, gram-negative, non-spore forming, flagellated, and motile, occurring as single cells or in pairs or multiples (Fig. 1). Colonies of strain 2002 grown aerobically on tryptic soy agar (TSA) or solidified nutrient broth, appear pink-orange, smooth, convex, and circular with a 1-2 mm diameter. When grown anaerobically on acetate $(10 \mathrm{mM})$ and $\mathrm{NO}_{3}{ }^{-}(10 \mathrm{mM})$, rod-shaped cells of strain 2002 were ca. $0.5 \mu \mathrm{m}$ in diameter and $1.5 \mu \mathrm{m}$ in length. Hemolytic activity was observed when strain 2002 was grown aerobically on TSA with 5\% sheep's blood (Environmental Microbiology Laboratory, Inc. Part \#1643). Strain 2002 grew over a temperature range $15-40^{\circ} \mathrm{C}$ with an optimal growth temperature of $37^{\circ} \mathrm{C}$. No growth was observed at $4^{\circ} \mathrm{C}$ and $45^{\circ} \mathrm{C}$. Growth was observed over a $\mathrm{pH}$ range of 6.75-8.0 and salinity $(\mathrm{NaCl})$ range of $0-1 \%$. Optimal $\mathrm{pH}$ and salinity were determined to be 7.25 and $0 \%$ respectively.

Phylogenetic and chemotaxonomic comparisons Pairwise comparison of $16 \mathrm{~S}$ rRNA gene sequences of cultivated bacteria identified Pseudogulbenkiania subflava as the nearest cultured relative (99.3\% 16S rRNA gene sequence identity) and an uncultured bacterial clone affiliated with iron-manganese nodules (GenBank accession\# EF492895; (He et al. 2008)). Phylogenetic analysis of the complete $16 \mathrm{~S}$ rRNA gene sequence of pure culture representatives placed strain 2002 in a clade with $P$. subflava and separated strain 2002 from the closely related genera Paludimonas, Gulbenkiania, Chromobacterium, and Aquitalea, as well as and
Table 1 Phopholipid fatty acid composition of strain $2002^{\mathrm{T}}$ grown under heterotrophic conditions $(10 \mathrm{mM}$ Acetate and $\left.10 \mathrm{mM} \mathrm{NO}_{3}{ }^{-}\right)$and lithoautotrophic conditions (10 $\mathrm{mM} \mathrm{FeCl} 2$ and $5 \mathrm{mM} \mathrm{NO}_{3}{ }^{-}$)

\begin{tabular}{lcc}
\hline & Mol \% heterotrophically grown & Mol \% lithoautotrophically grown \\
\hline Saturated & & \\
$14: 0$ & 0.89 & 0 \\
$15: 0$ & 0.34 & 36.74 \\
$16: 0$ & 36.67 & 0 \\
$17: 0$ & 0.05 & 1.06 \\
$18: 0$ & 0.4 & \\
Branched chain monounsaturated & & 0 \\
br19:1 & 0.1 & \\
Monounsaturated & & 0 \\
$16: 1 \omega 9 \mathrm{c}$ & 0.18 & 23.53 \\
$16: 1 \omega 7 \mathrm{c}$ & 32.82 & 0.98 \\
$16: 1 \omega 7 \mathrm{t}$ & 0.19 & 0.61 \\
$16: 1 \omega 5 \mathrm{c}$ & 0.35 & 0 \\
$17: 1$ & 0.06 & 21.15 \\
Cy17:0 & 15.45 & 14.73 \\
$18: 1 \omega 7 \mathrm{c}$ & 11.82 & 0.53 \\
$18: 1 \omega 7 \mathrm{t}$ & 0 & 0 \\
$18: 1 \omega 5 \mathrm{c}$ & 0.13 & 0.68 \\
Cy19:0 & 0.47 & 0 \\
Hydroxy & & \\
3 OH16:0 & 0.09 & \\
\hline & & \\
\hline & &
\end{tabular}


other pure culture relatives of the family Nesseriaceae in the order Neisseriales within the Betaproteobacteria (Fig. 2). Commercial (Deutsche Sammlung von Mikroorganismen und Zellkulturen $\mathrm{GmbH}$, DSMZ) determination of the $\mathrm{G}+\mathrm{C}$ content (Mesbah et al. 1989) of the genomic DNA of strain 2002 gave a value of $64 \mathrm{~mol} \%$, within the range of the DNA base composition described within the family Neisseriaceae (44-69\%; Tonjum 2005); Pseudogulbenkiania subflava (63\%), Paludimonas spp. (63\%; Kwon et al. 2008), Gulbenkiania spp. (59\%; Vaz-Moreira et al. 2007), Chromobacterium spp. (65-68 mol\%; Gillis \& Logan 2005), and Aquitalea spp. (65\%; Lau et al. 2006).
The major phospholipid fatty acids identified under lithoautotrophic and heterotrophic growth conditions were

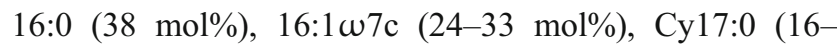
$21 \mathrm{~mol} \%$ ), and 18:1 $\omega_{7 \mathrm{c}}(12-15 \mathrm{~mol} \%$; Table 1). Similar phospholipids fatty acid profiles were obtained under both growth conditions. A subsequent analysis of the whole cell fatty acid content of strain 2002 identified the predominant

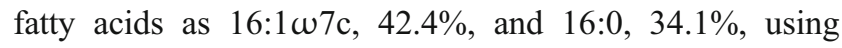
previously described methods (Komagata \& Suzuki 1987; MIDI 2001). Other fatty acids detected greater than $1 \mathrm{~mol}$

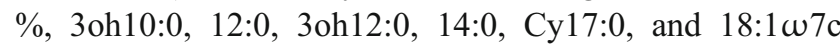
(Table 2) totaled $21.2 \mathrm{~mol} \%$. Principle components and

Table 2 Phenotypic and biochemical characteristics of strain 2002 (1) and relative type strains of the closely related genera within the family Neisseriaceae, Psuedogulbenkiania subflava BP-5T (2), Pauldibacterium yongneupense 5YN8-15T (3), Chromobacterium violaceum

ATCC 12472T (4), Chromobacterium subtsugae PRAA4-1T (5), Aquitalea magnusonii TRO-001-1DR8T (6), and Gulbenkiania mobilis $\mathrm{E} 4 \mathrm{FC} 31 \mathrm{~T}$ (7)

\begin{tabular}{|c|c|c|c|c|c|c|c|}
\hline Characteristic & 1 & $2^{\mathrm{a}}$ & $3^{\mathrm{b}}$ & $4^{\mathrm{c}}$ & $5^{\mathrm{f}}$ & $6^{\mathrm{g}}$ & $7^{\mathrm{h}}$ \\
\hline Isolation source & $\begin{array}{l}\text { Freshwater lake } \\
\text { sediment }\end{array}$ & Stream water & Wetland peat & Soil/water & Soil & Humic lake & $\begin{array}{l}\text { Municipal } \\
\text { wastewater }\end{array}$ \\
\hline Colony color & Pink-orange & Yellow & & Violet & Violet & Tan & No pigment \\
\hline DNA G $+\mathrm{C}$ content $(\mathrm{mol} \%)$ & 64 & 63 & 63 & $65-68$ & 65 & 59 & 63 \\
\hline Growth Temperature & $15-40$ & $15-42$ & $4-35$ & $28-40$ & $4-40$ & $28-37$ & $15-45$ \\
\hline $\mathrm{pH}$ Growth & $6.75-8$ & $6-8$ & $4-8$ & $5-8$ & $4.5-9.0$ & $5-8$ & $5.5-9$ \\
\hline $\mathrm{NaCl}$ tolerance $(\%)$ & $<1$ & $<1$ & $<5$ & $<4$ & $<3$ & $<1.5$ & $<3$ \\
\hline Urease & + & - & - & $-{ }^{\mathrm{e}}$ & NT & - & - \\
\hline Lithoautotrophic & + & NT & NT & - & NT & NT & - \\
\hline \multicolumn{8}{|l|}{ Carbon utilization of } \\
\hline Maltose & + & + & + & - & NT & - & - \\
\hline Glucose & + & + & + & + & + & + & - \\
\hline Sucrose & + & + & NT & - & - & - & - \\
\hline Trehalose & + & + & NT & + & + & - & - \\
\hline Capric acid & + & + & - & $+^{\mathrm{e}}$ & + & NT & + \\
\hline Mannose & - & - & - & + & + & - & - \\
\hline$N$-acetylglucosamine & - & - & + & + & + & + & - \\
\hline \multicolumn{8}{|l|}{ Use of electron acceptors } \\
\hline Nitrous oxide & + & - & NT & $-{ }^{\mathrm{d}}$ & - & + & - \\
\hline \multicolumn{8}{|l|}{ Fermentation of } \\
\hline Glucose & - & - & + & + & + & + & - \\
\hline Ribose & - & - & - & + & NT & - & - \\
\hline $\mathrm{HCN}$ production & - & NT & NT & + & NT & NT & - \\
\hline Hydrolysis of Gelatin & - & NT & - & + & + & - & - \\
\hline
\end{tabular}

\footnotetext{
NT Not tested

${ }^{a}$ Characteristics of P. subflava obtained from Kwon et al. (2008) and Lin et al. (2008)

${ }^{\mathrm{b}}$ Characteristics of $P$. yongneupense obtained from Kwon et al. (2008)

${ }^{\mathrm{c}}$ Characteristics of $C$. violaceum obtained from Gillis \& Logan (2005) unless otherwise noted

${ }^{\mathrm{d}}$ Characteristics of $C$. violaceum obtained from Bazylinski et al. (1986)

${ }^{\text {e }}$ Characteristics of $C$. violaceum obtained from the Identification table of the bioMérieux API 20 NE kit

${ }^{\mathrm{f}}$ Characteristics of $C$. subtsugae obtained from Martin et al. (2007) unless otherwise noted

${ }^{g}$ Characteristics of $A$. magnusonii obtained from Lau et al. (2006) unless otherwise noted

${ }^{\mathrm{h}}$ Characteristics of G. mobilis obtained from Vaz-Moreira et al. (2007) unless otherwise noted
} 
cluster analyses (Minitab 15.1.1.0) of the whole cell fatty acid data indicated that strain 2002 was chemotaxonomically similar to $P$. subflava but different from other near relatives in pure culture, Paludimonas spp., Microvirgula spp., Gulbenkiania spp., Chromobacterium spp., Aquitalea spp. (Fig. 3a \& b). Principal component analysis extracted two factors which accounted for $86 \%$ of the total variance (Fig. 3a), and clearly placed strain 2002 in a cluster with $P$. subflava (Fig. 3b).

Metabolic characterization Phenotypic characterization was conducted with a commercial biochemical kit, API 20
NE (bioMérieux), according to the manufacturer's instructions using supplemented freshwater basal medium. Strain 2002 tested positive for oxidase, catalase, urease, and arginine dihydrolase, and is capable of utilizing D-glucose, D-malate, potassium gluconate, capric acid, malic acid, and trisodium citrate. Strain 2002 cannot utilize L-arabinose, Dmannose, D-mannitol, $N$-acetylglucosamine, adipic acid, or phenylacetic acid and it does not produce hydrogen sulfide, gelatinase, $\beta$-glucosidase, or $\beta$-galactosidase (Table 2). Strain 2002 had been previously described as capable of anaerobically growing with $\mathrm{Fe}(\mathrm{II})$ as an electron donor coupled to the reduction of nitrate under autotrophic
Fig. 3 Principle components analysis of whole cell fatty acids of strain 2002 and closely related genera. The first two factors extracted account for $86 \%$ of the total variance. Inclusion of the third factor accounts for $97 \%$ of the total variance and further separates strain 2002 from Pauldibacterium, Gulbenkiania, Aqualitea and Chromobacterium strains. a Cluster analysis of the chemotaxonomic data set supported the separation of strain 2002 from Pauldibacterium, Gulbenkiania, Aqualitea and Chromobacterium strains and supported the similarities of the whole cell fatty acid content of strain 2002 with Pseudogulbenkiania subflava. b Clusters in the principle components analysis are denoted by the circles

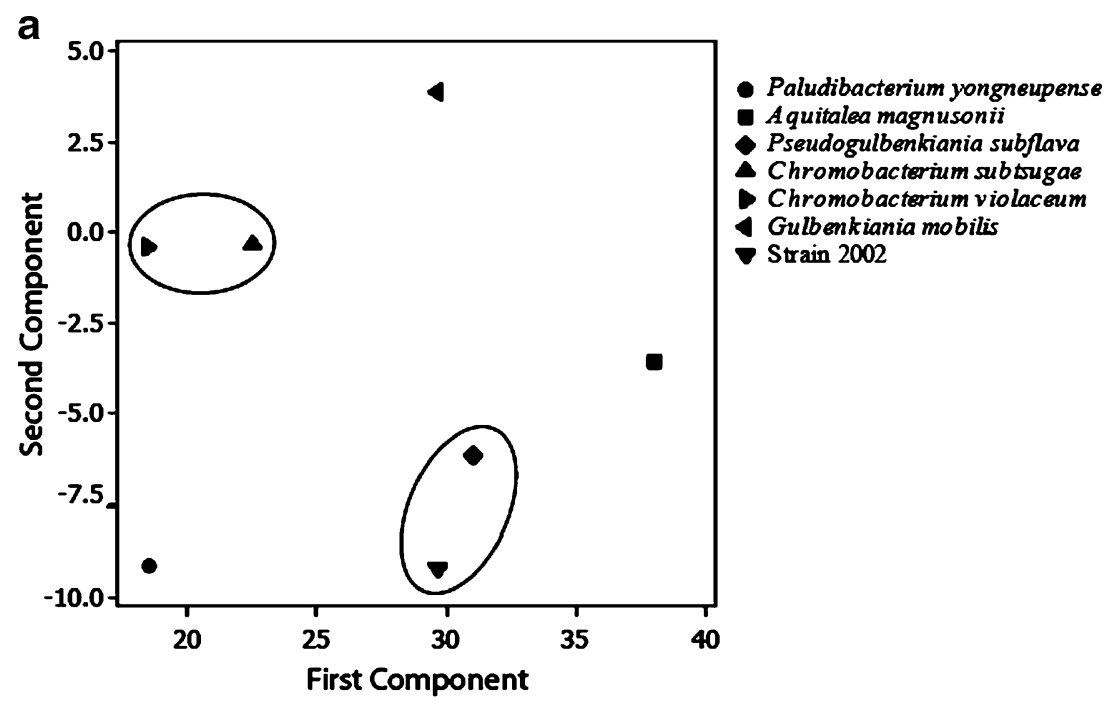

b

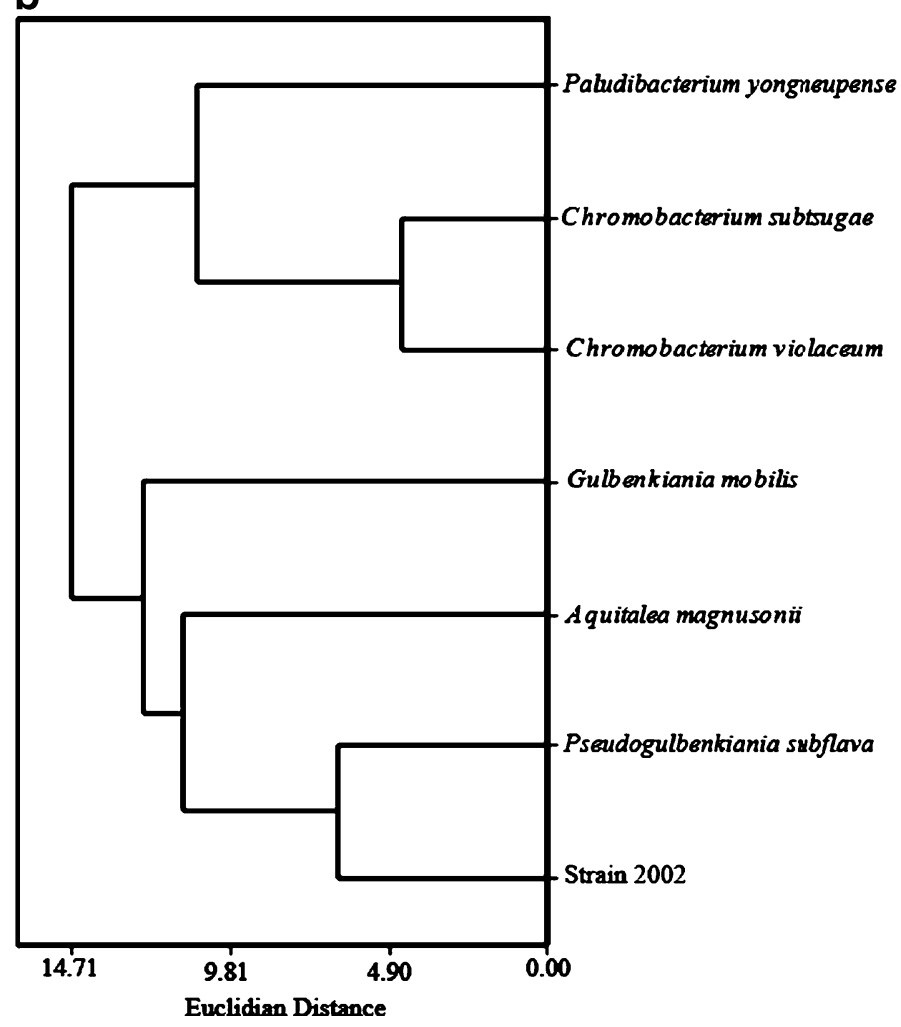


conditions (Weber et al. 2006b). Difference spectrum of the $\mathrm{Fe}(\mathrm{II})$-reduced minus nitrate oxidized cytochrome content of whole cells of strain 2002 revealed an absorption spectrum consistent with $c$-type cytochromes (absorption maxima at a wavelength at 424, 521, and $553 \mathrm{~nm}$; Fig. 4). In addition to the ability of strain 2002 to oxidize Fe(II), this bacterium has also previously been shown to oxidize uraninite, U(IV), in the presence of nitrate (Weber KA et al., 2009). In contrast to the oxidation of Fe(II) and U(IV), strain 2002 was incapable of anaerobically utilizing Mn(II) as an electron donor under these growth conditions (Table 3).

In the absence of $\mathrm{Fe}(\mathrm{II})$, strain 2002 grew heterotrophically with several simple organic compounds including acetate, propionate, butyrate, ethanol, pyruvate, and succinate as the sole carbon and energy source (Table 3). In addition, strain 2002 is also capable of utilizing other short chain volatile fatty acids, a variety of simple dicarboxylic acids, hexoses, yeast extract, and casamino acids as well as the long-chain fatty acids palmitic acid, stearic acid, lauric acid, behenic acid, and lignoceric acid as the sole carbon and energy source with nitrate as the terminal electron acceptor (Table 3).

Strain 2002 was relatively limited in the range of alternative electron acceptors used and with acetate as the electron donor; it grew aerobically or anaerobically with nitrate, nitrite, or nitrous oxide. Denitrification by strain 2002 terminated with the production of dinitrogen gas (Fig. 5). Reduction of $\mathrm{Fe}(\mathrm{III})$ to $\mathrm{Fe}(\mathrm{II})$ was observed in the initial transfer of an anaerobic acetate oxidizing, nitratereducing culture into fresh anaerobic medium amended with Fe(III)-NTA as the sole electron acceptor, however

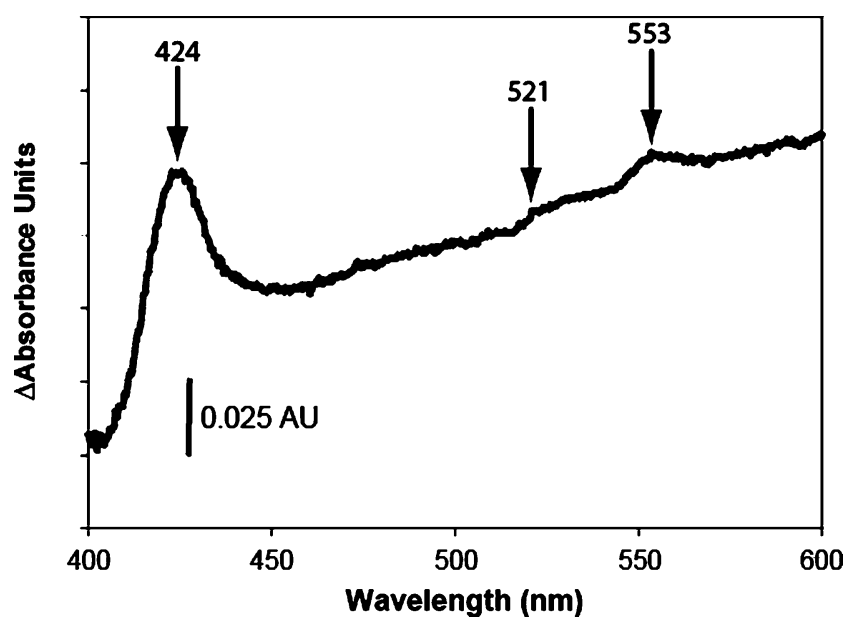

Fig. 4 Whole cell difference spectrum of the Fe(II) reduced minus nitrate oxidized cytochrome content within intact live cells of strain 2002 suspended in anoxic (100\% $\mathrm{N}_{2}$ atmosphere) PIPES buffer (20 mM, pH7.0). Arrows indicate absorption maxima with the corresponding wavelength denoted above the arrow. Vertical scale bar indicates a change of 0.025 absorbance units
Table 3 Electron donors and accepters tested

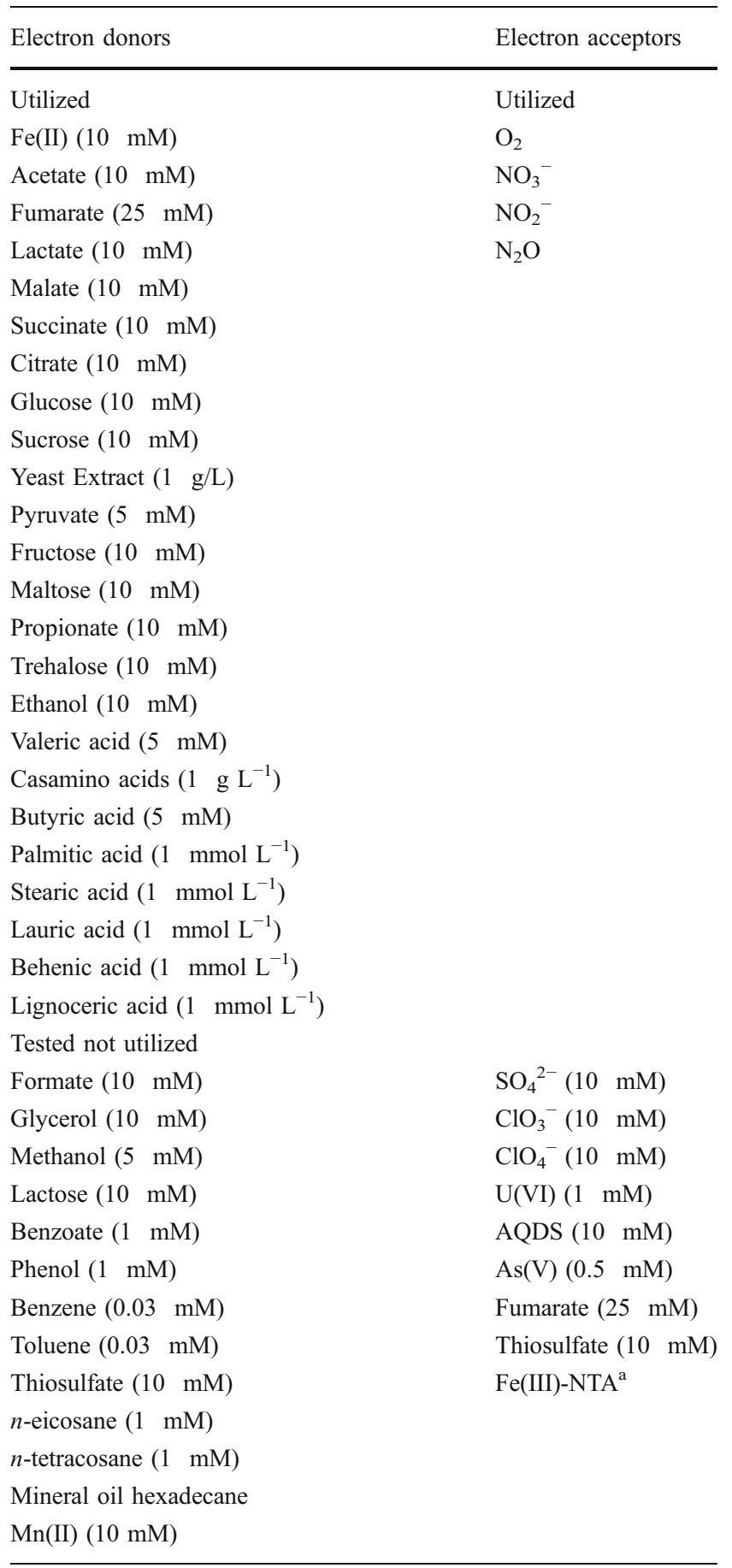

${ }^{\mathrm{a}}$ Strain 2002 could not be consistently maintained under Fe(III) reducing conditions, however Fe(III) reduction was observed in initial transfers

strain 2002 could not be continuously cultured under $\mathrm{Fe}$ (III)-reducing conditions (Weber et al. 2006b). In contrast to Chromobacterium spp., strain 2002 is not capable of fermentation as no growth was observed with any of the above electron donors or in complex organic medium containing yeast extract $\left(1 \mathrm{~g} \mathrm{~L}^{-1}\right)$, casamino acids $\left(1 \mathrm{~g} \mathrm{~L}^{-1}\right)$, 


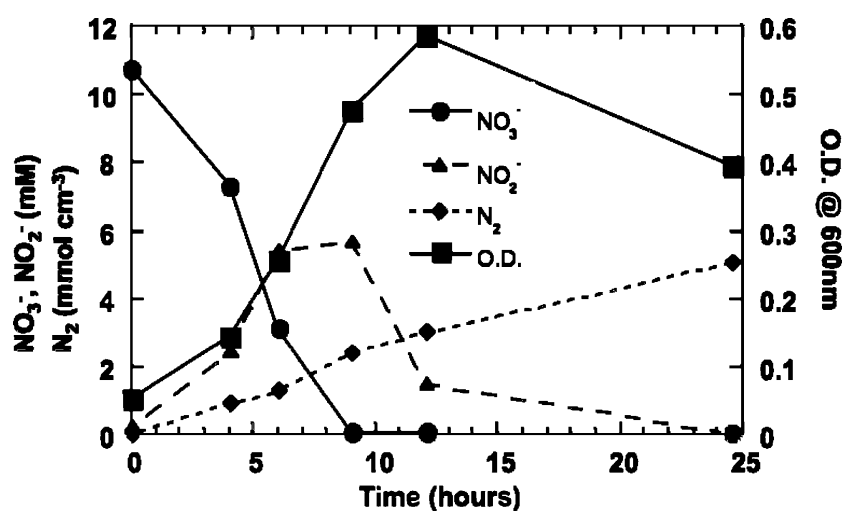

Fig. 5 Denitrification by strain 2002. Error bars indicate standard deviation of triplicate samples. filled inverted triangle Optical density, filled circle $\mathrm{NO}_{3}{ }^{-}$; filled upright triangle Live $\mathrm{NO}_{2}^{-}$, filled diamond $\mathrm{N}_{2}$

or glucose $(10 \mathrm{mM})$ unless a suitable electron acceptor was added. Strain 2002 was capable of incorporating $\mathrm{CO}_{2}$ into biomass when grown under autotrophic nitrate-dependent Fe(II)-oxidizing conditions (Weber et al. 2006b).

\section{Discussion}

Strain 2002 was previously described as capable of anaerobically growing with $\mathrm{Fe}$ (II) as an electron donor coupled to the reduction of nitrate under autotrophic conditions (Weber et al. 2006b). To date, strain 2002 remains the only mesophilic isolate in pure culture described as capable of autotrophic growth with $\mathrm{Fe}$ (II) serving as the sole electron donor. Isolation of strain 2002 from freshwater lake sediments harboring an abundant nitrate-dependent Fe(II)oxidizing microbial community suggests that microorganisms such as this could play a significant role in iron biogeochemical cycling and iron mineral formation in freshwater sediments. Given the ability of strain 2002 to utilize not only $\mathrm{Fe}$ (II) but also simple dicarboxylic acids, short chain volatile fatty acids, hexoses, yeast extract, casamino acids and long-chain fatty acids, it is thus likely that strain 2002 also plays a significant role in the degradation of organic matter in freshwater soils and sedimentary environments. Strain 2002 represents a recently recognized lineage within the family Neisseriaceae as determined by phylogenetic and chemotaxonomic analyses (Figs. 2 and 3). The recent identification of P. subflava, strain 2002, and uncultured bacterial clones affiliated with rice roots, iron-manganese nodules, and freshwater lake sediments (He et al. 2008; Scheid et al. 2004; Tamaki et al. 2005; Weber et al. 2006b) indicates that this genus is present in various surface soil/sedimentary environments and could potentially play a role in metal redox cycling. Given the significance of biogenic $\mathrm{Fe}(\mathrm{III})$ oxide precipitation to iron biogeochemical cycling and metal mobility (Weber et al. 2006a), it is necessary to understand the phylogenetic and metabolic characters of strain 2002.

Strain 2002 was capable of autotrophic growth with $\mathrm{Fe}$ (II) as the sole electron donor (Weber et al. 2006b). Consistent with previously published reports demonstrating the metabolic role of $c$-type cytochromes in anaerobic iron oxidation (Chaudhuri et al. 2001; Croal et al. 2007; Jiao et al. 2007), the difference spectrum of the Fe(II) reduced cytochrome content in cells of strain 2002 suggested that c-type cytochromes in strain 2002 may also be involved in $\mathrm{Fe}(\mathrm{II})$ oxidation (Fig. 4). While strain 2002 has been demonstrated to oxidize Fe(II) as well U(IV) (Weber KA et al., 2009), physiological characterization revealed that $\mathrm{Mn}(\mathrm{II})$ could not serve as an electron donor. While the net reaction of neutrophilic, anaerobic $\mathrm{Mn}$ (II) oxidation may be energetically favorable according to Eq. 1, the initial nitrate reduction reaction to nitrite would consume energy (Eq. 2). As such, the unfavorable thermodynamics of this initial reaction step may preclude strain 2002 from using $\mathrm{Mn}(\mathrm{II})$ as an electron donor under conditions tested in this study.

$$
\begin{aligned}
5 \mathrm{Mn}(\mathrm{II}) & +2 \mathrm{NO}_{3}^{-}+4 \mathrm{H}_{2} \mathrm{O} \rightarrow 5 \mathrm{MnO}_{2}+\mathrm{N}_{2} \\
& +8 \mathrm{H}^{+}\left(-55.8 \mathrm{~kJ} \mathrm{~mol}^{-1} \text { electron }\right) \\
\mathrm{Mn}(\mathrm{II})+ & \mathrm{NO}_{3}^{-}+\mathrm{H}_{2} \mathrm{O} \rightarrow \mathrm{MnO}_{2}+\mathrm{NO}_{2}^{-} \\
& +2 \mathrm{H}^{+}\left(2.48 \mathrm{~kJ} \mathrm{~mol}^{-1} \text { electron }\right)
\end{aligned}
$$

Strain 2002 does not have the ability to produce cyanide. As such, strain 2002 could not mobilize metals via the formation of metal-cyanide complexes, in a similar manner to C. violaceum (Brandl et al. 2007; Reith et al. 2007). However, the ability of strain 2002 to directly oxidize metals can directly influence metal mobility in the environment (Chaudhuri et al. 2001; Cornell \& Schwertmann 2003; Lack et al. 2002b; Weber et al. 2001; Weber et al. 2006c). A recent study demonstrated the potential bioremediative applicability of this metabolism for the attenuation of soluble contaminating heavy metals and radionuclides in aquifer systems (Lack et al. 2002b). In that study, stimulation of nitratedependent $\mathrm{Fe}$ (II) oxidation resulted in the rapid precipitation and immobilization of over $50 \%$ of the uranium and $80 \%$ of the cobalt in solution within five days.

To date, C. violaceum and strain 2002, represent the members within the family Neisseriaceae capable of metabolically influencing metal biogeochemical cycling. While there are many metabolic dissimilarities from strain 2002 there are several metabolic similarities with the nearest pure culture relative $P$. subflava. These two organisms are capable of using the following carbon sources: maltose, glucose, sucrose, trehalose, and capric acid (Table 2). In 
contrast to strain 2002, P. subflava tested negative for urease and nitrous oxide reduction (Table 2). Together, the phylogenetic, chemotaxonomic, and phenotypic distinctions between strain 2002 and other members of the family Neisseriaceae support placement as a member of the Psuedogulbenkiania genus $(=$ ATCC BAA-1479 = DSM 18807).

Acknowledgments This research was supported by the Department of Energy, Natural and Accelerated Bioremediation Program, through grants \#DE-FG02-98ER63592 to JDC and LAA. We sincerely thank Dr. Gordon Vrdoljak for the scanning electron micrograph of strain 2002.

Open Access This article is distributed under the terms of the Creative Commons Attribution Noncommercial License which permits any noncommercial use, distribution, and reproduction in any medium, provided the original author(s) and source are credited.

\section{References}

Bazylinski DA, Palome E, Blakemore NA, Blakemore RP (1986) Denitrification by Chromobacterium violaceum. Appl Environ Microbiol 52:696-699

Beller HR (2005) Anaerobic, Nitrate-Dependent Oxidation of U(IV) Oxide Minerals by the Chemolithoautotrophic Bacterium Thiobacillus denitrificans. Appl Environ Microbiol 71:2170-2174

Beller HR, Legler TC, Bourguet F, Letain TE, Kane SR, Coleman MA (2009) Identification of c-type cytochromes involved in anaerobic, bacterial U(IV) oxidation. Biodegradation 20:45-53. doi:10.1007/s10532-008-9198-y

Benz M, Brune A, Schink B (1998) Anaerobic and aerobic oxidation of ferrous iron at neutral $\mathrm{pH}$ by chemoheterotrophic nitratereducing bacteria. Arch Microbiol 169:159-165

Brandl H, Lehmann S, Faramarzi MA (2007) Mobilization of silver, gold, and platinum from solid materials by $\mathrm{HCN}$-forming microorganisms. Adv Mat Res 20-21:50-53

Bruce RA, Achenbach LA, Coates JD (1999) Reduction of (per) chlorate by a novel organism isolated from paper mill waste. Environ Microbiol 1:319-329

Chaudhuri SK, Lack JG, Coates JD (2001) Biogenic magnetite formation through anaerobic biooxidation of $\mathrm{Fe}(\mathrm{II})$. Appl Environ Microbiol 67:2844-2848

Ciania A, Gossa K-U, Schwarzenbach RP (2005) Light penetration in soil and particulate minerals. Eur J Soil Sci 56:561-574

Cornell RM, Schwertmann U (2003) The iron oxides: structure, properties, reactions, occurrences and uses, 2nd edn. WILEY-VCH, Weinheim

Corpe WA (1951) A study of the wide spread distribution of chromobacterium species in soil by a simple technique. J Bacteriol. 62:515-517

Croal L, Jiao Y, Newman D (2007) The fox operon from Rhodobacter strain SW2 promotes phototrophic Fe(II) oxidation in Rhodobacter capsulatus SB1003. J Bacteriol 189:1774-1782

Edwards KJ, Rogers DR, Wirsen CO, McCollom TM (2003) Isolation and characterization of novel psychrophilic, neutrophilic, Feoxidizing, chemolithoautotrohic $\alpha$ - and $\gamma$-Proteobacteria from the deep sea. Appl Environ Microbiol 69:2906-2913

Finneran KT, Housewright ME, Lovley DR (2002) Multiple influences of nitrate on uranium solubility during bioremediation of uraniumcontaminated subsurface sediments. Environ Microbiol 4:510-516

Gillis M, Logan NA (2005) Genus IV. Chromobacterium Bergonzini 1881, $153^{A L}$. In: Brenner DJ, Kreig NR, Staley JT (eds) Bergey's manual of systematic bacteriology. Springer, New York, pp 824-827
Hafenbradl D et al (1996) Ferroglobus placidus gen. nov., sp. nov. a novel hyperthermophilic archaeum that oxidizes $\mathrm{Fe}^{2+}$ at neutral pH under anoxic conditions. Arch Microbiol 166:308-314

Hall TA (1999) BioEdit: a user-friendly biological sequence alignment editor and analysis program for Windows 95/98/NT. Nucleic Acids Symp Ser 41:95-98

He J, Zhang L, Jin S, Zhu Y, Liu F (2008) Bacterial communities inside and surrounding soil iron-manganese nodules. Geomicrobiol J 25:14-24

Huelsenbeck JP, Ronquist F (2001) MRBAYES: Bayesian inference of phylogenetic trees. Bioinformatics 17:754-755

Hungate RE (1969) A roll tube method for cultivation of strict anaerobes. Methods Microbiol 3B:117-132

Hungria $\mathrm{M}$ et al (2005) Genetic characterization of Chromobacterium isolates from black water environments in the Brazilian Amazon. Lett Appl Microbiol 41:17-23

Jiao YJ, Yongqin, Newman DN, Dianne K (2007) The pio operon is essential for phototrophic Fe(II) oxidation in Rhodopseudomonas palustris TIE-1. J Bacteriol 189:1765-1773

Komagata K, Suzuki K (1987) Lipid and cell-wall analysis in bacterial systematics. Methods Microbiol 19:161-208

Kwon S-W, Byung-Yong Kim W-GK, Kwan-Hee Yoo, Seung-Hee Yoo, Jung-A Son, Hang- Yeon Weon (2008) Paludibacterium yongneupense gen. nov., sp. nov., isolated from a wetland, Yongneup, in Korea. Int J Syst Evol Microbiol 58:190-194

Lack JG, Chaudhuri SK, Chakraborty R, Achenbach LA, Coates JD (2002a) Anaerobic biooxidation of Fe(II) by Dechlorosoma suillum. Microb Ecol 43:424-431

Lack JG, Chaudhuri SK, Kelly SD, Kemner KM, O'Connor SM, Coates JD (2002b) Immobilization of radionuclides and heavy metals through anaerobic bio-oxidation of Fe(II). Appl Environ Microbiol 68:2704-2710

Lau H-T, Faryna J, Triplett EW (2006) Aquitalea magnusonii gen. nov., sp. nov., a novel Gram-negative bacterium isolated from a humic lake. Int. J. Syst. Evol. Microbiol 56:867-871

Lin M-C, Chou J-H, Arun AB, Young C-C, Chen W-M (2008) Pseudogulbenkiania subflava gen. nov., sp. nov., isolated from a cold spring. Int J Syst Evol Microbiol 58:2384-2388

Martin PAW, Gundersen-Rindal D, Blackburn M, Buyer J (2007) Chromobacterium subtsugae sp. nov., a betaproteobacterium toxic to Colorado potato beetle and other insect pests. Int J Syst Evol Microbiol 57:993-999

Mesbah M, Premachandran U, Whitman W (1989) Precise measurement of the $\mathrm{G}+\mathrm{C}$ content of deoxyribonucleic acid by high performance liquid chromatography. Int J Syst Bacteriol 39:159167

MIDI I (2001) Sherlock Microbial Identification System References

Reith F, Lengke MF, Falconer D, Craw D, Southam G (2007) Geomicrobiology of gold. ISME J 2007:567-584

Roden EE, Lovely DR (1993) Dissimilatroy Fe(III) Reduction by the marine microorganism Desulfuromonas acetoxidans. Appl Environ Microbiol 59:734-742

Scheid D, Stubner S, Conrad R (2004) Identification of rice root associated nitrate, sulfate and ferric iron reducing bacteria during root decomposition. FEMS Microbiol Ecol 50:101-110

Sheloblina ES, VanPraagy CG, Lovley DR (2003) Use of ferric and ferrous iron containing minerals for respiration by Desulfitobacterium frappieri. Geomicrobiol J 20:143-156

Singleton DR, Furlong MA, Peacock AD, White DC, Coleman DC, Whitman WB (2003) Solirubrobacter pauli gen. nov., sp. nov., a mesophilic bacterium within the Rubrobacteridae related to common soil clones. Int J Syst Bacteriol 53:485-490

Straub KL, Buchholz-Cleven BEE (1998) Enumeration and detection of anaerobic ferrous iron- oxidizing, nitrate-reducing bacteria from diverse European sediments. Appl Environ Microbiol 64:48464856 
Straub KL, Benz M, Schink B, Widdel F (1996) Anaerobic, nitratedependent microbial oxidation of ferrous iron. Appl Environ Microbiol 62:1458-1460

Straub KL, Rainey FA, Widdel F (1999) Rhodovulum iodosum sp. nov, and Rhodovulum robiginosum sp. nov., two new marine phototrophic ferrous-iron-oxidizing purple bacteria. Int J Syst Bacteriol 49:729-735

Straub KL, Schonhuber W, Buchholz-Cleven B, Schink B (2004) Diversity of ferrous iron- oxidizing, nitrate-reducing bacteria and their involvement in oxygen-independent iron cycling. Geomicrobiol J 21:371-378

Tamaki $\mathrm{H}$ et al (2005) Comparative analysis of bacterial diversity in freshwater sediment of a shallow eutrophic lake by molecular and improved cultivation-based techniques. Appl Environ Microbiol 71:2162-2169

Thomsen T, Kong Y, Nielsen P (2007) Ecophysiology of abundant denitrifying bacteria in activated sludge. FEMS Microbiol Ecol 60:370-382

Tonjum T (2005) Neisseriaceae Prevot 1933, $119^{\mathrm{AL}}$ emnd. Dewhirst, Paster and Bright 1989, 265. In: Brenner DJ, Kreig NR, Staley JT (eds) Bergey's manual of systematic bacteriology. Springer, New York, pp 775-776

Vasconcelos ATR, Almeida DF, Almeida FC, Almeida LGP, Almeida R, Alves-Gomes JA, Andrade et al (2003) The complete genome sequence of Chromobacterium violaceum reveals remarkable and exploitable bacterial adaptability. Proc Natl Acad Sci USA 100:11660-11665

Vaz-Moreira I, Nobre MF, Nunes OC, Manaia CM (2007) Gulbenkiania mobilis gen. nov., sp. nov., isolated from treated municipal wastewater. Int J Syst Evol Microbiol 57:1108-1112

Weber KA et al. (2009) Significance of microbially-mediated anaerobic oxidative dissolution of uraninite: a means of survival mobilizing a radionuclide (submitted)

Weber KA, Picardal FW, Roden EE (2001) Microbially catalyzed nitrate-dependent oxidation of biogenic solid-phase Fe(II) compounds. Environ Sci Technol 35:1644-1650

Weber KA, Achenbach LA, Coates JD (2006a) Microorganisms pumping iron: anaerobic microbial iron oxidation and reduction. Nat Rev Microbiol 4:752-764

Weber KA, Pollock J, Cole KA, O'Connor SM, Achenbach LA, Coates JD (2006b) Anaerobic nitrate-dependent Iron(II) biooxidation by a novel, lithoautotrophic, Betaproteobacterium, strain 2002. Appl Environ Microbiol 72:686-694

Weber KA, Urrutia MM, Churchill PF, Kukkadapu RK, Roden EE (2006c) Anaerobic redox cycling of iron by freshwater sediment microorganisms. Environ Microbiol 8:100-113

Wetzel RG, Likens GE (1991) Limnological analyses. Springer, New York Widdel F, Schnell S, Heising S, Ehrenreich A, Assmus B, Schink B (1993) Ferrous iron oxidation by anoxygenic phototrophic bacteria. Nature 362:834-836 